\title{
Information Embedded in Directors and Officers Insurance Purchases
}

\author{
Manu Gupta and Puneet Prakash \\ Finance Insurance and Real Estate, Virginia Commonwealth University, $301 \mathrm{~W}$ Main St, Richmond, \\ VA 23284, U.S.A.
}

We examine corporate purchases of Directors and Officers (D\&O) liability insurance and find that in addition to governance quality it contains managers' private information. In particular, we find that insider control in excess of insider share holdings is jointly associated with lower D\&O coverage limits and higher firm performance. The result holds when deductibles, corporate governance characteristics and litigation risk factors are controlled for. Our finding is consistent with an asymmetric information hypothesis in financial markets which posits that managers possess private information about firm risk. Our findings differ from existing literature that shows that D\&O insurance purchases primarily reflect firm's governance quality and litigation risk. The evidence supports the policy prescription advanced in earlier studies which call for mandatory public disclosure of $\mathrm{D} \& \mathrm{O}$ insurance purchases since it contains additional information for the market.

The Geneva Papers (2012) 37, 429-451. doi:10.1057/gpp.2012.27

Keywords: Directors and Officers insurance; corporate governance; information; risk

\section{Introduction}

Lawsuits against Directors and Officers (D\&O) accumulate when shareholders attribute their realised losses to the managers' failure to provide accurate and timely information on firm health and risk exposures. Directors of corporations are also known to resign or not come aboard in for-profit companies in the absence of D\&O insurance. ${ }^{1}$ Indeed, the criticality of D\&O insurance can be assessed from the fact that directors of even not-for-profit companies are advised to act in the same manner as directors of corporations when D\&O insurance is not available. ${ }^{2}$ These facts highlight the importance of D\&O insurance. Since D\&O liability insurance safeguards firms' directors and executives against litigation by firms' stakeholders for actions and decisions they take during the course of operations of the firm, the insurance purchase depends on litigation risk and managerial behaviour of the insured firm. In this paper, we examine the information content of D\&O insurance. The passage of the Dodd-Frank Act 2010, which envisages increased transparency in financial markets, highlights the importance of this area of research. Our findings suggest D\&O insurance purchases convey additional information to the financial markets.

\footnotetext{
${ }^{1}$ Romano (1989).

2 See Hazen and Hazen (2012).
} 
430

The existing literature analysed $\mathrm{D} \& \mathrm{O}$ insurance purchases primarily from the perspective of corporate governance and found that firm's governance quality, litigation risk and size are determinants of $\mathrm{D} \& \mathrm{O}$ insurance purchases (limits and premiums). If better governance lowers litigation risk, the relationship between good governance and $\mathrm{D} \& \mathrm{O}$ insurance purchases should be negative. Core ${ }^{3}$ reports better governance quality results in lower limits and premiums. O'Sullivan ${ }^{4}$ finds that firms with a higher percentage of outside directors and a lower percentage of insider holdings are more likely to purchase D\&O insurance. Firm size and litigation risk affect the likelihood of insurance purchase ${ }^{5}$ and the limits and premiums ${ }^{6}$ positively.

Few studies also focus on the information content of D\&O insurance. Chalmers et al. $^{7}$ study purchase of $\mathrm{D} \& \mathrm{O}$ insurance in the context of information asymmetry between the market and firms. If managers of firms exploit their superior inside information, the amount of insurance coverage chosen prior to the firm's initial public offering (IPO) will be related to the post-offering performance of the issuing firm's shares. Consistent with this hypothesis, the authors report a significant negative relation between the three-year post-IPO stock price performance and the insurance coverage purchased in conjunction with the IPO. The authors attribute their findings to managerial opportunism. Consistent with distortionary effects of D\&O insurance on managerial incentives, Lin et al. $^{8}$ report that acquirer firms with higher levels of $\mathrm{D} \& \mathrm{O}$ insurance pay higher acquisition premiums and their acquisitions appear to exhibit lower synergies.

While D\&O insurance premiums and limits are determined by governance quality, it is yet to be established if $\mathrm{D} \& \mathrm{O}$ insurance contains information beyond the easily observable governance characteristics ${ }^{9}$ typically studied in prior works. Since insurance markets are characterised by adverse selection, theory dictates that insurance contracts also reflect private managerial information and/or behaviour, as low risk firms signal their quality to separate themselves from high risk firms. In this paper, we examine whether D\&O insurance purchases contain additional information on firm quality other than directly observable governance characteristics. The paper differs from Chalmers et al. ${ }^{7}$ who study the information content of D\&O insurance when the firm is privately held. We focus on firms trading in the secondary markets and find that $\mathrm{D} \& \mathrm{O}$ insurance purchases by firms reveal information on firm quality beyond the firm's governance.

We construct a panel data set on D\&O insurance purchases by Canadian firms for our study since such data is publicly available. Panel data enables us to study changes in $\mathrm{D} \& \mathrm{O}$ insurance limits and premiums, and leads to a richer analysis than possible in a cross section of firms. We apply firm fixed-effects model in a simultaneous equation

\footnotetext{
${ }^{3}$ Core (2000).

${ }^{4}$ O'Sullivan (1997).

${ }^{5}$ O'Sullivan $(1997,2002)$.

${ }^{6}$ Core $(1997,2000)$.

${ }^{7}$ Chalmers et al. (2002).

${ }^{8}$ Lin et al. (2011).

${ }^{9}$ These include, but are not limited to, percentage of outside directors, percentage of shares held by insiders, voting rights held by insiders, whether CEO is Chairman, stock compensation for managers, etc.
} 
framework, one equation each for premiums and limits, and find that excess insider control, that is - insider voting rights unrelated to insider ownership, is related positively to a firm's return on assets and operating performance but negatively to coverage limits. This result holds when we control for other governance characteristics and litigation risk factors, and the insurance deductible. The joint effect of excess insider control on performance and $\mathrm{D} \& \mathrm{O}$ insurance coverage limits shows that the insurance purchase decision contains information on behaviour of insiders bestowed with excess control.

Usually, in the insurance market, firms signal their quality through deductibles. ${ }^{10}$ However, Core ${ }^{11}$ hypothesizes and finds that size of deductible in this market is dependent on factors he associated with litigation risk and not on governance. We also find that after controlling for litigation risk factors, the insurance deductibles do not affect coverage limits or premiums, suggesting that deductibles do not contain additional information on a firm's quality in the D\&O insurance market when other business risk factors which affect litigation risk $^{12}$ are accounted for.

However, choice of deductible is only one of many screening criteria insurers adopt in underwriting. Signals in insurance markets comprise greater sharing of losses by the insured with the insurer through deductibles and/or coinsurance, so that the indemnity sought is lower than the loss amounts. Crocker and Snow ${ }^{13}$ argue, for given loss amounts a deductible is coverage restriction which can be implemented through policy limits. Thus, our finding, that increased excess insider control is simultaneously associated with reduction in coverage limits and better performance, provides evidence that the choice of $\mathrm{D} \& \mathrm{O}$ insurance coverage limits conveys information about a firm's business and/or managerial quality in the secondary market when deductibles, litigation risk and observable governance characteristics are controlled for. ${ }^{14}$

We also find that stock-option-based executive compensation increases coverage limits and premiums. Stock option compensation incentivises managers into taking more risk. ${ }^{15}$ As insiders of firms, managers are privy to more information about the firms' litigation risk than insurers. The positive association between stock option and coverage limit is thus consistent with coverage limit conveying information about a manager's assessment of firm's litigation risk.

In addition, coverage limits go up when anti-takeover mechanisms are put in place (thus increasing the likelihood of managerial entrenchment due to decreased market discipline), and both insurance premiums and coverage limits increase when outside

\footnotetext{
${ }^{10}$ See Puelz and Snow (1994) for a detailed discussion.

${ }^{11}$ Core (1997).

${ }^{12}$ Following Core (1997) we use litigation risk interchangeably with business risk factors which affect litigation risk.

${ }^{13}$ Crocker and Snow (2011).

${ }^{14}$ We cannot extricate in our model if the reduction in coverage is due to the managers' own risk appetite or the private information they possess about the firm's book of business. Consequently, we refrain from using the word "signalling" which is associated with the latter in the finance literature.

${ }^{15}$ Milidonis and Stathopoulos (2011).
} 
blockholders ${ }^{16}$ depart (signalling less external monitoring). Premiums decline for firms whose shares are held by an outside blockholder. These findings corroborate that corporate governance characteristics are associated with a firm's insurance premium and thus its litigation risk.

We find no evidence that coverage limits or insurance premiums are related to changes in: board independence, the percentage of independent directors that the incumbent CEO appoints, or the existence of CEO employment contracts. Additionally, coverage and premiums do not change in response to changes in CEO-Chair duality or changes in golden parachute status. Finally, we find no relationship between changes in board size and D\&O coverage or premiums. Overall, we find mixed evidence of association of a firm's observable governance characteristics with its $\mathrm{D} \& \mathrm{O}$ coverage or premium.

Increases in firm size and the decision to list on a U.S. exchange result in large increases in both coverage and premiums. Managers of firms that have been sued earlier do not change their coverage, but insurers raise the firm's premium by about 18 per cent. The finding is consistent with results obtained in studies of other insurance lines of business, where premiums are based upon the insurer's previous loss experience with the insured exposure. When Canadian firms initially cross-list on U.S. exchanges, managers raise their coverage limits by about 50 per cent, while insurers nearly double the premiums of firms (about 82 per cent). This finding supports the assertion that the legal environment in which a business operates affects litigation risk.

The main contribution of our paper is that we find evidence that D\&O insurance purchases contain information on hard to observe managerial behaviour and/or private knowledge. This information is in addition to what is reflected in the formal corporate governance and risk characteristics. In particular, we find evidence that D\&O coverage limits contain information on how managerial control in excess of the amount determined by their claim on the firms' shares is exercised, ceteris paribus. To the best of our knowledge, this paper's findings are the first in support of the survey study of Baker and Griffith ${ }^{17}$ which hypothesizes that D\&O insurance captures "deep governance". ${ }^{18}$ Our study is motivated by the fact that insurers glean information on risk types in their underwriting process to avoid failure due to adverse selection. Therefore, we examine if there is additional information encapsulated in D\&O insurance data. We abstract away from determinants of the demand for D\&O insurance.

The rest of the paper is organised as follows. The following section provides a review of the literature and theoretical motivation. Our methodology and data selection is then detailed. We provide descriptive statistics and regression results under the sections Descriptive statistics and Regression results and finally, we offer conclusions.

\footnotetext{
${ }^{16}$ A blockholder is defined as a stockholder who owns more than 5 per cent of company stock.

${ }^{17}$ Baker and Griffith (2007).

${ }^{18}$ More on this in the literature review section.
} 


\section{Literature review}

Firms purchase D\&O insurance to hedge against litigation risk. The legal environment in which a firm operates, as well as firm-specific factors influence the litigation risk of the firm and thus D\&O insurance coverage and premiums. Holderness ${ }^{19}$ argues that $\mathrm{D} \& \mathrm{O}$ insurers act as external monitors of the management. Insurers assess a firm's dividend policy, acquisition plans and stock ownership of the board when making pricing decisions. Insurance policy conditions also incentivise managers to monitor each other. The failure of one executive to reveal material facts when applying for insurance can result in loss of coverage for all. ${ }^{20} \mathrm{D} \& \mathrm{O}$ insurance coverage and premium is thus argued to be related to a firm's corporate governance structure. $^{21}$

The aforesaid governance or monitoring hypothesis with respect to D\&O insurance suggests that weaker corporate governance allows managers greater freedom to take actions potentially detrimental to shareholder interests thus raising litigation risk. Consistent with the governance hypothesis, Core ${ }^{11}$ finds, for a cross section of firms, that $\mathrm{D} \& \mathrm{O}$ insurance coverage is positively related with insider control. Similarly, Core $^{3}$ reports both premiums and coverage limits are negatively related with governance quality. O'Sullivan ${ }^{4}$ provides evidence that the likelihood of D\&O insurance purchase is negatively related to insider ownership and positively to percentage of outside directors on the board. In sum, these studies show that corporate governance practices of firms affect D\&O insurance purchases.

Recent studies argue that D\&O insurance also encapsulates information beyond easily observable governance characteristics. Baker and Griffith ${ }^{17}$ survey the D\&O insurance market, and conclude that $\mathrm{D} \& \mathrm{O}$ underwriting decisions consider "deep governance" such as "culture" (the system of incentives and constraints embedded within the firm) and "character" of its management (in particular its ability to rationalise around the rules and whether it comprises "risk-takers above the norm"), "rather than the formal governance variables that are typically studied in D\&O insurance studies". In accordance with "deep governance", Boyer and Stern ${ }^{22}$ find income trusts in Canada, which have a "riskier governance structure", pay higher D\&O insurance premiums compared with a common equity firm. Boubakri et al. ${ }^{23}$ report no insignificant relation between D\&O coverage and premiums, and insider ownership. Similarly, Chen and $\mathrm{Li}^{24}$ do not find that D\&O insurance (either purchase or coverage limits) impacts quality of corporate governance. In this study, we examine whether there is indeed additional information in $\mathrm{D} \& \mathrm{O}$ insurance purchases beyond the observable governance variables typically studied.

\footnotetext{
${ }^{19}$ Holderness (1990).

${ }^{20}$ For a detailed exposition of the argument why D\&O insurer acts as a monitor of firms, see Holderness (1990).

${ }^{21}$ See Kyrtsis (2011) for a review.

22 Boyer and Stern (2012).

${ }^{23}$ Boubakri et al. (2008).

${ }^{24}$ Chen and Li (2010).
} 
Financial markets are beset by information asymmetry problems manifested in adverse selection and moral hazard. These problems are compounded when there is separation of ownership and control. ${ }^{25}$ Under these circumstances, firms' shareholders endeavour to adopt means to reduce information asymmetry between themselves and controlling managers. Using insurance theory, we argue D\&O insurance purchases are one such instrument.

Rothschild and Stiglitz ${ }^{26}$ show that for cases with only two possible outcomes, no loss or a single loss of given size, insurance market failure due to pooling of good and bad risks is avoidable when good risk can signal their risk type. They achieve this by electing to have partial coverage. Doherty and Schlesinger ${ }^{27}$ extend the Rothschild and Stiglitz's model to a distribution of losses, and find that market failure is more likely to result when losses are random. However, a separating equilibrium still exists if good risks can signal their risk type using a combination of deductibles and coinsurance, that is, by choosing indemnity which is less than their loss.

As per the Rothschild and Stiglitz ${ }^{26}$ argument, when news is good or managers are low risk type, then greater insider ownership and control (via voting rights), proxying for insiders having private information and/or managerial risk type ${ }^{28}$ may be associated with managers electing partial coverage. Partial coverage can be implemented using a combination of coinsurance/deductibles or lower limits. ${ }^{13}$ The Rothschild and Stiglitz ${ }^{26}$ argument thus makes it imperative that we go beyond the dichotomy of the D\&O insurance purchase decision, that is whether a firm carries D\&O insurance, and analyse insurance limits. We undertake this task in the paper.

We therefore diverge from the existing literature and study whether D\&O insurance coverage contains information on managers' superior knowledge on firm quality and/ or managerial behaviour not easily captured by formal governance variables. We control for the deductibles, observable governance characteristics and business factors that determine litigation risk. Our methodology and information on data follows.

\section{Methodology and data}

We examine how information asymmetry between firm's managers and insurers affects demand and price for D\&O insurance. We employ a panel data for our analysis, along the lines of Boyer ${ }^{29}$ and differ from purely cross-sectional analyses as in Core $^{6}$ and O'Sullivan. ${ }^{30}$ The panel data set helps us capture within-firm variations over time, not just variations between firms.

\footnotetext{
${ }^{25}$ Fama and Jensen (1983).

${ }^{26}$ Rothschild and Stiglitz (1976).

${ }^{27}$ Doherty and Schlesinger (1995).

${ }^{28}$ There is ample evidence that insider holdings and voting rights are associated with private information of managers. For information content of insider ownership, see Demsetz and Villalonga (2001), and for a review of literature on the association between voting rights and private managerial information, see Attig et al. (2006).

${ }^{29}$ Boyer (2003).

${ }^{30}$ O'Sullivan $(1997,2009)$.
} 
We employ a variant of the two-step methodology introduced by Chiappori and Salaniè. ${ }^{31}$ In their bivariate set-up, one equation is for the choice of coverage and the other for risk.

$$
\begin{gathered}
\text { Coverage }_{i}=f\left(X_{i}\right)+\varepsilon_{i}, \\
\text { Risk }_{i}=g\left(X_{i}\right)+\delta_{i} .
\end{gathered}
$$

Since the two equations are determined together, the correlation between the residuals of each of the regressions can be estimated. If the correlation is statistically different from zero, then the two regressions are determined simultaneously, confirming endogeneity between coverage and risk.

Core $^{3}$ also uses modified versions of Eqs. (1) and (2) to study a cross section of firms. Cross-sectional data however may include deviations from long-run equilibrium that tend to be correlated with the independent variables, resulting in inconsistent estimates of structural parameters. The use of panel data enables one to model adjustments arising out of these deviations, thus reducing the likelihood of inconsistent estimation. ${ }^{32}$ Nevertheless, cross-sectional estimation is useful in providing stylised facts to guide the construction of dynamic models.

For the aforesaid reasons, we modify the two-step ordinary least squares (OLS) cross-sectional analysis in $\mathrm{Core}^{3}$ for our panel data analysis in the following manner:

$$
\begin{gathered}
\mathrm{LN}(\text { limit })_{i t}=\lambda_{0}+\lambda_{0 i}+\lambda_{1} \text { gov_quality }_{i t}+\lambda_{2} \text { bus_risk }_{i t}+\varepsilon_{1 i t}, \\
\begin{aligned}
\mathrm{LN}(\text { prem })_{i t}= & \beta_{0}+\beta_{0 i}+\beta_{1} \text { gov_quality }_{i t}+\beta_{2} \text { bus_risk }_{i t} \\
& +\beta_{3} \mathrm{LN}(\text { limit })_{i t}+\varepsilon_{2 i t} .
\end{aligned}
\end{gathered}
$$

Substituting LN(limit $)_{i t}$ of Eq. (3) into Eq. (3-1) gives us the following reduced form equation for premiums,

$$
\mathrm{LN}\left(\text { prem }_{i t}=\delta_{0}+\delta_{0 i}+\delta_{1} \text { gov_quality }_{i t}+\delta_{2} \text { bus_risk }_{i t}+\beta_{3} \varepsilon_{1 i t}+\varepsilon_{2 i t},\right.
$$

where Eq. (3) forms the coverage regression, and the residual obtained from it $\left(\varepsilon_{1}\right)$ is inserted into the premium equation (Eq. (4)). Each $\delta_{i}=\beta_{3} \lambda_{i}+\beta_{i}$, and these coefficients of Eq. (4) capture both direct and indirect (arising out of the impact on coverage limits) effect of explanatory variables on premiums. For each firm $i$ at time $t$, $\mathrm{LN}$ (Limit) is the limit of coverage of the D\&O policy, gov_quality is a set of governance variables, and bus_risk is a set of business risk variables which affect litigation risk. In the model represented in Eqs. (3) and (4), the former (coverage limit) is endogenous choice of the firm, and the premiums in the latter are determined in conjunction with coverage choice.

\footnotetext{
${ }^{31}$ Chiappori and Salaniè (1997).

32 Schmalensee (1989).
} 
While we employ several variables for gov_quality (Table 1), our main variable of interest is excess control, which equals insider voting rights not explained by insider holdings, and is estimated using the following regression:

$$
\text { Insider vote } \text { It }=a_{0}+a_{i}+b \times \text { Insider ownership } i t+\mu_{i t} .
$$

The residual $\left(a_{i}+\mu_{i t}\right)$ captures the variation in insider vote unexplained by insider ownership and forms our measure of excess control. It serves as a proxy for insider information and/or unobserved managerial risk-taking behaviour. Please refer to Table 1 for the construction of insider vote, insider ownership and all other variables.

Finally, in order to determine if this excess control is related to firm performance, we run a regression of the form:

$$
\text { Firm performance }_{i t}=w_{0}+w_{i} \times \text { Excess control }_{i t}+\text { controls }_{i t}+\text { err }_{i t} \text {. }
$$

We use return on assets (ROA) and operating profit ratio (EBITDA to Total Assets ratio) to measure performance. Both performance measures are net of the premium expense.

We follow Core $^{3}$ to construct our data set. Data on firms' D\&O insurance policy and governance comes from proxy statements, and litigation data from annual reports. Unlike the U.S., Canadian regulators require disclosure of D\&O insurance in a firm's proxy statements and therefore our sample consists of firms listed on the Toronto Stock Exchange (TSX). The stock returns data is taken from DataStream and accounting data from Canadian Compustat. We start in 1998 since Frieswick $^{33}$ notes there was an increase in litigation against firms following the Dey Report of 1994 which led to changes in the TSX disclosure requirements. Also, proxy statements and annual reports became available online on the Canadian System for Electronic Document Analysis and Retrieval (SEDAR) in 1998. The length of underwriting cycle in Canada is approximately six years, ${ }^{34}$ and so is the median tenure of directors. ${ }^{35}$ Given that boards are also staggered in many Canadian firms, we expect to cover almost a full underwriting cycle and the board's serving period over the sample period of five years ending in 2002 .

Our data thus consists of 255 observations for 93 Canadian firms traded on TSX that reported their D\&O insurance premiums, coverage limits and deductibles in 1998, 2000 and 2002. ${ }^{36}$ Data was available in all three years for 69 firms, while data was available in only two years for the remaining 24 firms. The panel size of 93 firms is

\footnotetext{
${ }^{33}$ Frieswick (2002).

${ }^{34}$ Cummins and Outreville (1987) report a cycle length of 6.24 in automobile insurance and 6.65 years on average for all property and liability lines in Canada.

${ }^{35}$ Park and Shin (2004) report the median tenure is six years for outside directors and seven years for inside directors in Canada.

${ }^{36}$ Our initial sample consisted of 735 firms over 1998, 2000 and 2002 that had D\&O insurance information in their proxy statement. However, on merging with the Datastream database and Canadian Compustat we were left with 255 observations that had D\&O insurance data as well as stock returns data in Datastream and accounting data in Canadian Compustat.
} 
Table 1 Descriptive statistics of sample firms

\begin{tabular}{|c|c|c|c|c|c|c|}
\hline Variables & Definition & & All years & 1998 & 2000 & 2002 \\
\hline$N$ & Number of observations & & 255 & 72 & 92 & 91 \\
\hline \multirow[t]{2}{*}{ D\&O premium } & Dollar amount of the annual & Mean & 172,891 & 151,938 & 150,542 & 212,063 \\
\hline & D\&O insurance premium & Median & 80,518 & 56,969 & 70,768 & 127,663 \\
\hline \multirow[t]{2}{*}{ D\&O limit } & Annual coverage limit & Mean & $54,099,046$ & $43,712,540$ & $49,207,992$ & $67,261,774$ \\
\hline & & Median & $23,821,548$ & $16,675,083$ & $23,137,436$ & $34,354,870$ \\
\hline \multirow{2}{*}{ D\&O deductible } & Insurance deductible & Mean & 755,121 & 878,484 & 661,887 & 751,773 \\
\hline & & Median & 131,933 & 95,286 & 92,549 & 137,419 \\
\hline \multirow[t]{2}{*}{ Insider votes } & Percentage of shares votes controlled by inside & Mean & $16.59 \%$ & $15.06 \%$ & $18.12 \%$ & $16.24 \%$ \\
\hline & directors & Median & $2.07 \%$ & $1.35 \%$ & $2.49 \%$ & $1.65 \%$ \\
\hline \multirow[t]{2}{*}{ Insider value } & Percentage of shares value owned by inside & Mean & $9.05 \%$ & $8.45 \%$ & $10.38 \%$ & $8.20 \%$ \\
\hline & directors & Median & $1.45 \%$ & $0.95 \%$ & $2.03 \%$ & $1.21 \%$ \\
\hline \multirow[t]{2}{*}{ D(outside blockholder) } & $=1$ when outside blockholder owns over $10 \%$ & Mean & 0.460 & 0.347 & 0.326 & 0.286 \\
\hline & of the stocks & Median & - & - & - & - \\
\hline \multirow[t]{2}{*}{ Board size } & Board size & Mean & 10.15 & 10.21 & 10.14 & 10.12 \\
\hline & & Median & 9.00 & 10.00 & 9.00 & 10.00 \\
\hline \multirow[t]{2}{*}{ Independent directors } & Number of independent directors as a percentage & Mean & $66.95 \%$ & $65.68 \%$ & $66.81 \%$ & $68.09 \%$ \\
\hline & of the board size & Median & $70.00 \%$ & $66.67 \%$ & $69.62 \%$ & $71.43 \%$ \\
\hline \multirow{2}{*}{$\begin{array}{l}\text { Independent director } \\
\text { appointments }\end{array}$} & Proportion of independent directors appointed & Mean & $46.02 \%$ & $44.33 \%$ & $46.39 \%$ & $47.01 \%$ \\
\hline & by $\mathrm{CEO}$ & Median & $50.00 \%$ & $42.86 \%$ & $50.00 \%$ & $50.00 \%$ \\
\hline \multirow[t]{2}{*}{$\mathrm{D}(\mathrm{CEO}$ is chairman $)$} & $=1$ if $\mathrm{CEO}$ is also board chair & Mean & 0.435 & 0.472 & 0.424 & 0.418 \\
\hline & & Median & - & - & - & - \\
\hline \multirow[t]{2}{*}{ Incentive compensation } & CEO stock incentive compensation as a & Mean & $34.82 \%$ & $26.33 \%$ & $34.98 \%$ & $41.38 \%$ \\
\hline & percentage of total compensation & Median & $30.09 \%$ & $15.06 \%$ & $26.54 \%$ & 43.15 \\
\hline \multirow[t]{2}{*}{$\mathrm{D}$ (employment contract) } & $=1$ if the CEO has employment contract & Mean & 0.737 & 0.694 & 0.728 & 0.780 \\
\hline & & Median & - & - & - & - \\
\hline \multirow[t]{2}{*}{$\mathrm{D}$ (golden parachute) } & $=1$ if CEO has a golden parachute & Mean & 0.435 & 0.403 & 0.424 & 0.473 \\
\hline & & Median & - & - & - & - \\
\hline \multirow{2}{*}{$\mathrm{D}$ (takeover deterrents) } & $=1$ if the firm has a staggered board, poison pill, & Mean & 0.357 & 0.361 & 0.348 & 0.363 \\
\hline & or any other takeover restrictions & Median & - & - & - & - \\
\hline \multirow[t]{2}{*}{ CEO experience } & Number of years the CEO has served on the & Mean & 8.91 & 7.92 & 8.88 & 9.77 \\
\hline & board of directors & Median & 7.00 & 6.00 & 7.00 & 7.00 \\
\hline
\end{tabular}


Table 1 (continued)

\begin{tabular}{|c|c|c|c|c|c|c|}
\hline Variables & Definition & & All years & 1998 & 2000 & 2002 \\
\hline \multirow[t]{2}{*}{ ROE } & \multirow{2}{*}{$\begin{array}{l}\text { Net income before extraordinary items divided by } \\
\text { ending equity }\end{array}$} & Mean & $13.49 \%$ & $12.39 \%$ & $17.16 \%$ & $10.65 \%$ \\
\hline & & Median & $13.72 \%$ & $12.32 \%$ & $16.56 \%$ & $13.72 \%$ \\
\hline & Total assets (million C\$) & Median & 862.63 & 647.94 & 886.84 & 940.74 \\
\hline \multirow[t]{2}{*}{$\mathrm{D}$ (prior litigation) } & \multirow{4}{*}{$\begin{array}{l}=1 \text { if the firm disclosed pending or prior } \\
\text { litigation in either its annual report or proxy } \\
=1 \text { if the firm has sales or assets in the U.S. }\end{array}$} & Mean & 0.369 & 0.306 & 0.337 & 0.451 \\
\hline & & Median & - & - & - & - \\
\hline \multirow[t]{2}{*}{ D(U.S. operations) } & & Mean & 0.359 & 0.347 & 0.359 & 0.363 \\
\hline & & Median & - & - & - & - \\
\hline \multirow[t]{2}{*}{ D(U.S. exchange listing) } & \multirow[t]{2}{*}{$=1$ if the firm is listed on U.S. exchange } & Mean & 0.380 & 0.319 & 0.359 & 0.451 \\
\hline & & Median & - & - & - & - \\
\hline
\end{tabular}

The sample includes 93 Canadian firms that disclose D\&O insurance data during two or more of following years: 1998, 2000 and 2002. Dollar values are expressed in constant 1995 Canadian dollars. Data on insurance and governance variables is gathered from firm proxy statement (from SEDAR). Accounting and stock price data is collected from Canadian Compustat and DataStream. Firm annual reports are used to identify prior litigations. 
comparable to Core's ${ }^{3}$ cross-sectional sample of 110 firms, hand collected prior to the advent of SEDAR.

We apply panel data firm fixed-effects regressions with standard errors corrected for heteroscedasticity. The firm fixed-effects approach controls for all time-invariant firm-specific omitted variables relevant to either the insurer's premium decision or the firm's choice of coverage limit.

\section{Descriptive statistics}

Table 1 presents variable definitions along with their mean and median. All values are reported in constant Canadian 1995 dollar terms. We convert any data that the firms report in U.S. dollars to Canadian dollars (C\$) using the year-end exchange rate.

The mean (median) premium is C\$ 172,891 (C\$ 80,518), while the mean deductible is C\$755,121 (C\$131,933). Mean (median) coverage limits are C\$54.1 million (C\$ 23.8 million). Accounting for deductibles, the median firm paid $0.34 \mathrm{C} \notin$ per $\mathrm{C} \$$ of $\mathrm{D} \& \mathrm{O}$ insurance coverage $(80,518 / 23.8$ million). Our premium and coverage limit data are similar to those of $\mathrm{Core}^{3}$ who reports a median premium of $\mathrm{C} \$ 103,477$ and a median coverage limit of C\$20.0 million. ${ }^{37}$

Analysis of D\&O contracts reveals there is a secular increase in premiums charged and coverage demanded as shown in Table 1. However, substantial changes occur in the insurance market by the events between the years 2000 and 2002. The increase is more pronounced in premiums. The median premium paid in 2002 is 80.4 per cent greater than its 2000 predecessor. Coverage limits increased 48.9 per cent over the same interval, indicating an increase in per unit price. The deductibles show a decline in 2000 before rising again in $2002 .^{38}$ The median deductible increases monotonically with the passage of time for those firms with data in all three years. The unit price of coverage after accounting for the deductible for the median firm falls from $0.34 \mathrm{C} \varnothing$ in 1998 to $0.30 \mathrm{C} \phi$ in 2000 , then increases to $0.37 \mathrm{C} \varnothing$ in 2002 signalling an increase of approximately 23 per cent between 2000 and 2002 .

The means and medians reported for the other variables differ little whether they are calculated for the full sample or for only those firms with data in all three years. Therefore, we report only the full sample statistics.

Among the remaining variables there is evidence of small changes over time. For example, fewer firms have unaffiliated blockholders, the percentage of independent directors increases slightly, CEO incentive compensation increases, litigation increases, and more of the firms cross-list on U.S. exchanges. Compared to the dramatic changes in the insurance variables, the governance structure and business risk variables appear relatively stable. Despite relative stability these measures of centrality (means and

\footnotetext{
${ }^{37}$ We also use 2003 C\$ values and do not find substantial changes in unit price of coverage. Since change of base year confirms that unit price remains low, it is unlikely that D\&O insurance prices of such small magnitudes will lead to changes in governance structures. Hence, governance structures can be safely assumed to be determined independently of D\&O insurance premiums.

38 Twenty firms with lower deductibles enter the sample in year 2000 and 19 firms with higher deductibles get added thereafter.
} 
Table 2 Changes in firm characteristics

\begin{tabular}{lccc}
\hline \multirow{2}{*}{ Continuous variables } & \multicolumn{2}{c}{ Percentage change across two years } \\
\cline { 2 - 3 } & $25^{\text {th }}$ percentile $(\%)$ & $50^{\text {th }}$ percentile $(\%)$ & $75^{\text {th }}$ percentile $(\%)$ \\
\hline Panel $A$ & & & \\
D\&O premium & -3.4 & 16.2 & 71.5 \\
D\&O limit & -2.9 & 4.6 & 66.6 \\
D\&O deductible & -4.1 & -2.9 & 4.7 \\
Insider votes & -31.7 & -3.8 & 5.8 \\
Insider value & -34.8 & -9.6 & 10.1 \\
CEO experience & 10.0 & 25.0 & 50.0 \\
Incentive compensation & -41.9 & -2.1 & 90.5 \\
Board size & -7.1 & 0.0 & 9.1 \\
Independent directors & -6.7 & 0.0 & 11.4 \\
Independent director appointments & -16.7 & 0.0 & 20.0 \\
ROE & -0.1 & 0.0 & 0.1 \\
Size & 0.4 & 23.4 & 59.9 \\
\hline
\end{tabular}

\begin{tabular}{|c|c|c|c|}
\hline \multirow[t]{2}{*}{ Dummy variables } & \multicolumn{3}{|c|}{ Percentage of firms experiencing change in dummy variables } \\
\hline & Decrease (\%) & No change (\%) & Increase $(\%)$ \\
\hline \multicolumn{4}{|l|}{ Panel B } \\
\hline D(outside blockholder) & 11.7 & 80.3 & 8.0 \\
\hline $\mathrm{D}(\mathrm{CEO}$ is chairman $)$ & 6.8 & 88.9 & 4.3 \\
\hline $\mathrm{D}$ (employment contract) & 1.2 & 92.6 & 6.2 \\
\hline D(golden parachute) & 1.9 & 90.7 & 7.4 \\
\hline $\mathrm{D}$ (takeover deterrents) & 0.6 & 95.7 & 3.7 \\
\hline D(U.S. operations) & 0.0 & 96.9 & 3.1 \\
\hline D(U.S. exchange listing) & 0.6 & 91.4 & 8.0 \\
\hline
\end{tabular}

Panel A describes the percentage change in continuous variables across two-year intervals. The three breakpoints between quartiles are reported. Panel B reports the percentage of changes that occurred in either direction. The sample includes 93 Canadian firms (with 255 observations and 162 pairs of change) that disclose D\&O insurance data during two or more of following years: 1998, 2000 and 2002. Variable definitions are given in Table 1.

medians) show variation with time and reveal possible within-firm variations so critical to the fixed-effects method.

Table 2 provides details on the within-firm variation in variables over time for the sample firms. For continuous variables, we calculate the percentage change across two-year intervals and report changes at the $25^{\text {th }}, 50^{\text {th }}$, and $75^{\text {th }}$ percentile levels in panel A. For dummy variables, we report the percentage of firms whose dummy variable changes in two-year intervals in panel $\mathrm{B}$.

Table 2, panel A shows that except for size and CEO experience, all continuous variables decrease for the $25^{\text {th }}$ percentile, while all variables increase for the $75^{\text {th }}$ percentile. The median changes are both positive and negative. Thus, we see that the distribution of continuous variables is dynamic and becomes more positively skewed in firms over time. Panel B reveals there is a net decrease in outside blockholders in 
firms over this period. It also shows that the firms increasingly split the role of the CEO from Chairman. For all other categorical variables, there is an increase within firms. Overall, panel B shows that even though there is stability within the firms (no change firms account for the highest percentage), there is still some variation between one wave to the next with the probability mass becoming positively skewed except for outside blockholders and the dummy for CEO is chairman.

Table 3 reports the mean and median percentage change in coverage limits and in premiums associated with different groups formed on the basis of changes (positive, negative or no change) in the explanatory variables. For example, the first row divides the 162 changes for the 255 firm years into three groups; cases where insider votes declined, remained the same, or increased. The 87 cases of declining insider votes are associated with a mean (median) coverage limit change of 59.1 per cent (21.9 per cent). For 22 cases of unchanged insider votes, the mean (median) coverage limit change is

Table 3 Changes in coverage limits and premiums associated with increases, decreases or stable explanatory variables

\begin{tabular}{|c|c|c|c|c|c|c|c|}
\hline \multirow[t]{2}{*}{ Variables } & & \multicolumn{3}{|c|}{ Percentage change in limit } & \multicolumn{3}{|c|}{ Percentage change in premium } \\
\hline & & Decrease & No change & Increase & Decrease & No change & Increase \\
\hline \multirow[t]{3}{*}{ Insider votes } & Mean & 59.1 & 23.4 & 35.3 & 69.1 & 16.1 & 43.4 \\
\hline & Median & 21.9 & -1.5 & 0 & 24.8 & 0 & 7.5 \\
\hline & $(\mathrm{N})$ & (87) & $(22)$ & (53) & $(87)$ & $(22)$ & (53) \\
\hline \multirow[t]{3}{*}{ Insider value } & Mean & 56.7 & 22.5 & 35.4 & 67.6 & 7.8 & 41.0 \\
\hline & Median & 20.6 & -2.9 & 0 & 25.0 & -0.9 & 4.6 \\
\hline & $(\mathrm{N})$ & $(92)$ & (13) & $(57)$ & $(92)$ & (13) & $(57)$ \\
\hline \multirow[t]{3}{*}{ CEO experience } & Mean & 16.5 & 141.1 & 49.5 & 29.7 & 78.7 & 56.9 \\
\hline & Median & 3.7 & 18.2 & 5.2 & 8.9 & 39.4 & 21.5 \\
\hline & $(\mathrm{N})$ & $(23)$ & (3) & $(136)$ & $(23)$ & (3) & $(136)$ \\
\hline \multirow[t]{3}{*}{ Incentive compensation } & Mean & 38.0 & 48.5 & 51.5 & 40.8 & 63.0 & 59.5 \\
\hline & Median & 5.1 & 45.7 & 4.0 & 8.4 & 32.3 & 20.5 \\
\hline & $(\mathrm{N})$ & $(56)$ & $(21)$ & (84) & $(56)$ & $(21)$ & (84) \\
\hline \multirow[t]{3}{*}{ Board size } & Mean & 39.0 & 46.6 & 51.9 & 40.2 & 42.7 & 77.0 \\
\hline & Median & 0 & 5.6 & 14.1 & 14.0 & 6.1 & 29.6 \\
\hline & $(\mathrm{N})$ & (41) & (67) & (54) & (41) & $(67)$ & (54) \\
\hline \multirow[t]{3}{*}{ Independent directors } & Mean & 33.5 & 51.8 & 53.5 & 46.4 & 58.5 & 56.3 \\
\hline & Median & 0 & 21.4 & 8.3 & 6.8 & 17.7 & 22.4 \\
\hline & $(\mathrm{N})$ & (54) & $(35)$ & (73) & (54) & $(35)$ & (73) \\
\hline \multirow{3}{*}{$\begin{array}{l}\text { Independent director } \\
\text { appointments }\end{array}$} & Mean & 29.8 & 49.3 & 58.3 & 44.3 & 53.8 & 52.5 \\
\hline & Median & -0.1 & 58.3 & 18.2 & 14.3 & 16.0 & 16.6 \\
\hline & $(\mathrm{N})$ & $(50)$ & (28) & $(71)$ & $(50)$ & $(28)$ & $(71)$ \\
\hline \multirow[t]{3}{*}{ ROE } & Mean & 50.2 & & 42.3 & 54.0 & & 53.0 \\
\hline & Median & 5.4 & & 4.5 & 28.7 & & 13.4 \\
\hline & $(\mathrm{N})$ & (86) & (0) & (76) & $(86)$ & $(0)$ & $(76)$ \\
\hline \multirow[t]{3}{*}{ Size } & Mean & 43.1 & & 47.5 & 49.3 & & 54.8 \\
\hline & Median & 3.1 & & 5.3 & 27.4 & & 14.4 \\
\hline & $(\mathrm{N})$ & (39) & (0) & $(123)$ & (39) & $(0)$ & $(123)$ \\
\hline \multirow[t]{3}{*}{ D(outside blockholders) } & Mean & 68.3 & 43.5 & 44.0 & 98.1 & 49.2 & 31.6 \\
\hline & Median & 17.0 & 4.6 & 4.0 & 4.1 & 19.0 & 8.3 \\
\hline & $(\mathrm{N})$ & (19) & (130) & (13) & (19) & (130) & (13) \\
\hline
\end{tabular}


Table 3 (continued)

\begin{tabular}{|c|c|c|c|c|c|c|c|}
\hline \multirow[t]{2}{*}{ Variables } & & \multicolumn{3}{|c|}{ Percentage change in limit } & \multicolumn{3}{|c|}{ Percentage change in premium } \\
\hline & & Decrease & No change & Increase & Decrease & No change & Increase \\
\hline \multirow[t]{3}{*}{$\mathrm{D}(\mathrm{CEO}$ is chairman $)$} & Mean & 8.6 & 50.1 & 31.5 & 25.4 & 53.8 & 90.4 \\
\hline & Median & -0.1 & 5.4 & 4.0 & 5.6 & 20.5 & 29.3 \\
\hline & $(\mathrm{N})$ & (11) & $(144)$ & (7) & $(11)$ & $(144)$ & (7) \\
\hline \multirow[t]{3}{*}{$\mathrm{D}$ (employment contract) } & Mean & 7.7 & 48.4 & 24.6 & -16.9 & 56.0 & 29.6 \\
\hline & Median & 7.7 & 4.5 & 14.7 & -16.9 & 21.4 & 0.3 \\
\hline & $(\mathrm{N})$ & (2) & $(150)$ & $(10)$ & (2) & $(150)$ & $(10)$ \\
\hline \multirow[t]{3}{*}{$\mathrm{D}$ (golden parachute) } & Mean & 31.9 & 46.6 & 47.9 & 120.2 & 53.8 & 32.4 \\
\hline & Median & 4.0 & 4.6 & 6.8 & 102.8 & 15.0 & 14.0 \\
\hline & $(\mathrm{N})$ & (3) & (147) & (12) & (3) & (147) & (12) \\
\hline \multirow[t]{3}{*}{$\mathrm{D}$ (takeover deterrents) } & Mean & -4.1 & 44.4 & 107.9 & -5.7 & 54.7 & 31.1 \\
\hline & Median & -4.1 & 4.6 & 73.1 & -5.7 & 17.7 & 0.7 \\
\hline & $(\mathrm{N})$ & (1) & $(155)$ & (6) & (1) & $(155)$ & (6) \\
\hline \multirow[t]{3}{*}{$\mathrm{D}$ (prior litigation) } & Mean & 67.5 & 42.4 & 65.0 & 25.2 & 51.1 & 80.9 \\
\hline & Median & 76.1 & 4.6 & 0 & 11.6 & 14.0 & 49.4 \\
\hline & $(\mathrm{N})$ & (8) & (134) & $(20)$ & (8) & (134) & $(20)$ \\
\hline \multirow[t]{3}{*}{ D(U.S. operations) } & Mean & & 46.6 & 42.5 & & 53.5 & 53.2 \\
\hline & Median & & 5.2 & -2.9 & & 15.0 & 70.7 \\
\hline & $(\mathrm{N})$ & $(0)$ & $(157)$ & (5) & $(0)$ & $(157)$ & (5) \\
\hline \multirow[t]{3}{*}{ D(U.S. exchange listing) } & Mean & -4.1 & 37.5 & 152.7 & 15.0 & 42.3 & 184.0 \\
\hline & Median & -4.1 & 4.5 & 116.4 & 15.0 & 13.1 & 174.2 \\
\hline & $(\mathrm{N})$ & (1) & (148) & (13) & (1) & (148) & (13) \\
\hline
\end{tabular}

This table reports mean and median percentage change in coverage limits and in premiums for firms grouped by their changes in the explanatory variables. Variable definitions are given in Table 1 . The sample includes 93 Canadian firms that disclose D\&O insurance data during two or more of following years: 1998, 2000 and 2002. Dollar values are expressed in constant 1995 Canadian dollars.

23.4 per cent $(-1.5$ per cent), and for 53 cases of increased insider votes, the mean (median) limit change is 35.3 per cent ( 0 per cent). Similar interpretation applies to each variable, with the table's last three columns reporting mean and median changes in the premium set by the insurer.

\section{Regression results}

The variables used in the study mirror Core $^{3}$ who undertakes a two-step crosssectional analysis as outlined earlier. ${ }^{39}$ We undertake several alternative regression models whose results are shown in Table 4. Each model examines how the manager's choice of coverage limit relates to changes in explanatory variables (Eq. (3)), and how changes in those variables relate to the insurance premium (Eq. (4)).

\footnotetext{
${ }^{39}$ We also undertake a year-by-year cross-sectional analysis to make a direct comparison to Core (2000) findings. Results are available on request from the authors. The significance of governance variables changes, while those of business risk variables are stable across years. Instability of the governance variables underscores the suitability of the proposed fixed-effects methodology.
} 
Table 4 Panel data fixed-effects regression estimates of manager's coverage choice and insurer's premium decision on governance and business risk variables

\begin{tabular}{|c|c|c|c|c|c|c|c|c|c|c|}
\hline \multirow[t]{2}{*}{ Variable } & \multicolumn{2}{|c|}{ Model 1} & \multicolumn{2}{|c|}{ Model 2} & \multicolumn{2}{|c|}{ Model 3} & \multicolumn{2}{|c|}{ Model 4} & \multicolumn{2}{|c|}{ Model 5} \\
\hline & $\operatorname{Ln}$ (Limit) & Ln(Premium) & $\operatorname{Ln}$ (Limit) & Ln (Premium) & $\operatorname{Ln}($ Limit $)$ & Ln(Premium) & $\operatorname{Ln}($ Limit $)$ & Ln(Premium) & $\operatorname{Ln}($ Limit $)$ & Ln(Premium) \\
\hline Intercept & $\begin{array}{l}15.08 * * * \\
(0.00)\end{array}$ & $\begin{array}{l}9.92 * * * \\
(0.00)\end{array}$ & $\begin{array}{l}14.95 * * * \\
(0.00)\end{array}$ & $\begin{array}{l}9.90 * * * \\
(0.00)\end{array}$ & $\begin{array}{l}14.72 * * * \\
(0.00)\end{array}$ & $\begin{array}{l}8.83 * * * \\
(0.00)\end{array}$ & $\begin{array}{l}15.21 * * * \\
(0.00)\end{array}$ & $\begin{array}{l}9.97 * * * \\
(0.00)\end{array}$ & $\begin{array}{l}15.39 * * * \\
(0.00)\end{array}$ & $\begin{array}{l}9.98 * * * \\
(0.00)\end{array}$ \\
\hline Insider votes & $\begin{array}{c}-1.45 \\
(0.18)\end{array}$ & $\begin{array}{c}-0.17 \\
(0.80)\end{array}$ & & & & & & & $\begin{array}{l}-2.04 * * * \\
(0.00)\end{array}$ & $\begin{array}{l}-2.36^{* * *} \\
(0.00)\end{array}$ \\
\hline Excess control & & & & & $\begin{array}{c}-2.25 * * \\
(0.04)\end{array}$ & $\begin{array}{c}-0.70 \\
(0.51)\end{array}$ & & & & \\
\hline Insider value & $\begin{array}{c}-0.54 \\
(0.69)\end{array}$ & $\begin{array}{c}-3.06 * * * \\
(0.00)\end{array}$ & $\begin{array}{c}-2.00 * * \\
(0.02)\end{array}$ & $\begin{array}{c}-3.23 * * * \\
(0.00)\end{array}$ & $\begin{array}{l}-2.14 * * * \\
(0.01)\end{array}$ & $\begin{array}{c}-3.14 * * * \\
(0.00)\end{array}$ & $\begin{array}{c}-2.02 * * * \\
(0.01)\end{array}$ & $\begin{array}{c}-3.05 * * * \\
(0.00)\end{array}$ & & \\
\hline D(outside blockholder) & $\begin{array}{c}-0.16^{* *} \\
(0.03)\end{array}$ & $\begin{array}{c}-0.19 * * \\
(0.02)\end{array}$ & $\begin{array}{c}-0.15^{* *} \\
(0.04)\end{array}$ & $\begin{array}{c}-0.19^{* *} \\
(0.02)\end{array}$ & $\begin{array}{c}-0.18^{* *} \\
(0.02)\end{array}$ & $\begin{array}{c}-0.19^{* * *} \\
(0.01)\end{array}$ & $\begin{array}{c}-0.16^{* *} \\
(0.02)\end{array}$ & $\begin{array}{c}-0.20^{* * * *} \\
(0.01)\end{array}$ & $\begin{array}{c}-0.17 * * \\
(0.02)\end{array}$ & $\begin{array}{c}-0.22^{* * * *} \\
(0.00)\end{array}$ \\
\hline Ln(board size) & & & & & $\begin{array}{c}-0.28 \\
(0.29)\end{array}$ & $\begin{array}{c}0.10 \\
(0.69)\end{array}$ & & & & \\
\hline Independent directors & $\begin{array}{c}0.31 \\
(0.32)\end{array}$ & $\begin{array}{c}-0.06 \\
(0.85)\end{array}$ & $\begin{array}{c}0.30 \\
(0.32)\end{array}$ & $\begin{array}{c}-0.06 \\
(0.85)\end{array}$ & $\begin{array}{c}0.26 \\
(0.43)\end{array}$ & $\begin{array}{c}-0.13 \\
(0.69)\end{array}$ & & & & \\
\hline Independent director appointments & $\begin{array}{c}0.02 \\
(0.91)\end{array}$ & $\begin{array}{c}0.02 \\
(0.93)\end{array}$ & $\begin{array}{c}0.05 \\
(0.79)\end{array}$ & $\begin{array}{c}0.02 \\
(0.92)\end{array}$ & $\begin{array}{c}-0.003 \\
(0.99)\end{array}$ & $\begin{array}{c}0.04 \\
(0.88)\end{array}$ & & & & \\
\hline Incentive compensation & & & & & $\begin{array}{l}0.28^{* * *} \\
(0.00)\end{array}$ & $\begin{array}{l}0.15^{*} \\
(0.08)\end{array}$ & $\begin{array}{l}0.24 * * * \\
(0.01)\end{array}$ & $\begin{array}{c}0.17^{*} \\
(0.06)\end{array}$ & $\begin{array}{l}0.27 * * * \\
(0.00)\end{array}$ & $\begin{array}{l}0.20 * * \\
(0.03)\end{array}$ \\
\hline $\mathrm{D}(\mathrm{CEO}$ is chairman $)$ & $\begin{array}{c}0.03 \\
(0.68)\end{array}$ & $\begin{array}{c}0.03 \\
(0.81)\end{array}$ & $\begin{array}{c}0.04 \\
(0.65)\end{array}$ & $\begin{array}{c}0.03 \\
(0.80)\end{array}$ & $\begin{array}{c}-0.01 \\
(0.99)\end{array}$ & $\begin{array}{c}0.02 \\
(0.84)\end{array}$ & & & & \\
\hline D(employment contract) & $\begin{array}{c}0.02 \\
(0.88)\end{array}$ & $\begin{array}{c}0.08 \\
(0.62)\end{array}$ & $\begin{array}{c}0.03 \\
(0.80)\end{array}$ & $\begin{array}{l}0.08 \\
(0.61)\end{array}$ & $\begin{array}{c}-0.01 \\
(0.93)\end{array}$ & $\begin{array}{c}0.03 \\
(0.83)\end{array}$ & & & & \\
\hline D(golden parachute) & $\begin{array}{c}0.02 \\
(0.82)\end{array}$ & $\begin{array}{c}-0.16 \\
(0.18)\end{array}$ & $\begin{array}{c}0.00 \\
(0.95)\end{array}$ & $\begin{array}{c}-0.17 \\
(0.17)\end{array}$ & $\begin{array}{c}0.02 \\
(0.87)\end{array}$ & $\begin{array}{c}-0.14 \\
(0.28)\end{array}$ & & & & \\
\hline $\mathrm{D}$ (takeover deterrents) & $\begin{array}{l}0.34 * * * \\
(0.01)\end{array}$ & $\begin{array}{c}0.20 \\
(0.25)\end{array}$ & $\begin{array}{l}0.34 * * * \\
(0.01)\end{array}$ & $\begin{array}{c}0.20 \\
(0.24)\end{array}$ & $\begin{array}{l}0.26^{*} \\
(0.09)\end{array}$ & $\begin{array}{c}0.15 \\
(0.33)\end{array}$ & $\begin{array}{l}0.34 * * * \\
(0.01)\end{array}$ & $\begin{array}{c}0.14 \\
(0.37)\end{array}$ & $\begin{array}{l}0.33 * * * \\
(0.01)\end{array}$ & $\begin{array}{c}0.13 \\
(0.42)\end{array}$ \\
\hline $\operatorname{Ln}(\mathrm{CEO}$ experience $)$ & $\begin{array}{c}0.06 \\
(0.35)\end{array}$ & $\begin{array}{c}0.08 \\
(0.21)\end{array}$ & $\begin{array}{c}0.06 \\
(0.36)\end{array}$ & $\begin{array}{c}0.08 \\
(0.21)\end{array}$ & $\begin{array}{c}0.06 \\
(0.37)\end{array}$ & $\begin{array}{c}0.08 \\
(0.25)\end{array}$ & & & & \\
\hline ROE & $\begin{array}{c}-0.11 \\
(0.55)\end{array}$ & $\begin{array}{r}-0.36^{*} \\
(0.07)\end{array}$ & $\begin{array}{c}-1.5 \\
(0.44)\end{array}$ & $\begin{array}{r}-0.36^{*} \\
(0.07)\end{array}$ & $\begin{array}{c}0.01 \\
(0.98)\end{array}$ & $\begin{array}{c}-0.34 \\
(0.11)\end{array}$ & $\begin{array}{c}-0.11 \\
(0.54)\end{array}$ & $\begin{array}{c}-0.31 \\
(0.11)\end{array}$ & $\begin{array}{c}-0.07 \\
(0.70)\end{array}$ & $\begin{array}{c}-0.31 \\
(0.12)\end{array}$ \\
\hline $\operatorname{Ln}(\operatorname{size})$ & $\begin{array}{l}0.27^{* * *} \\
(0.00)\end{array}$ & $\begin{array}{l}0.22 * * * \\
(0.00)\end{array}$ & $\begin{array}{l}0.27 * * * \\
(0.00)\end{array}$ & $\begin{array}{l}0.22 * * * \\
(0.00)\end{array}$ & $\begin{array}{l}0.25^{* * *} \\
(0.00)\end{array}$ & $\begin{array}{l}0.21^{* * *} \\
(0.00)\end{array}$ & $\begin{array}{l}0.27 * * * \\
(0.00)\end{array}$ & $\begin{array}{l}0.21^{* * *} \\
(0.00)\end{array}$ & $\begin{array}{l}0.27^{* * *} \\
(0.00)\end{array}$ & $\begin{array}{l}0.23 * * * \\
(0.00)\end{array}$ \\
\hline
\end{tabular}


Table 4 (continued)

This table presents the results of panel data firm fixed-effects regressions for explaining manager's coverage choices and insurer's premium decisions using firm's governance and business risk variables. Variable definitions are given in Table 1. Excess control equals Insider Votes orthogonal to Insider Value. The sample includes 93 Canadian firms that disclose D\&O insurance data during two or more of following years: 1998, 2000 and 2002 . Dollar values are expressed in constant 1995 Canadian dollars. Limit Residual is the error term of $\mathrm{Ln}$ (Limit) regression. Insider Votes is included in models 1 and 5 but excluded from models 2,3 and 4 because of its high correlation with Insider Value. Model 3 includes all governance variables whereas models 4 and 5 contain a parsimonious set of variables with either insider vote or insider value. Heteroscedastically consistent $p$-values are reported in parentheses. 
We have argued earlier that voting rights and equity ownership of insiders capture the degree of information asymmetry between the firm and outsiders, aside from being governance variables. Consequently, Model 1 contains both these measures of governance and information asymmetry. Contrary to expectation, neither displays significance in the coverage regressions while insider ownership shows a negative and significant effect on premiums. A correlation analysis reveals that the correlation coefficient between the levels of the two variables is 0.70 ( $p$-value $<0.0001$ ), while correlation coefficient for changes in the two is 0.9995 ( $p$-value $<0.0001$ ). Hence in order to avoid multicollinearity all remaining models include only one of the two measures. Our discussion below focuses on Model (3), since it contains all our variables of interest.

The coverage choice regression (measured by Ln(limit)) in Model 3, Table 4 shows that the D\&O insurance purchased is significantly related to some but not all governance characteristics. In this model, we add insider votes, board size, CEO's incentive compensation and the D\&O policy's deductible. Excess control, that is voting rights held by insiders that cannot be explained by the value of their holdings, is the residual of a firm-fixed-effects regression of insider votes on insider value (Eq. (5)).

We find a unit increase in excess control is associated with 2.25 unit decrease in insurance coverage $^{40}$ ( $p$-value 0.04). Unit increase in insider ownership value and addition of an outsider blockholder is associated with lower coverage by 2.14 units ( $p$-value 0.01 ) and 0.18 units ( $p$-value 0.02 ), respectively. When managers are incentivised to take more risk through stock options, the coverage limits increase by 0.28 units ( $p$-value 0.00 ) for a unit increase in stock options. The addition of takeover deterrents causes managerial entrenchment and reduces the role of market monitoring, and is associated with an increase in coverage limits of 0.26 ( $p$-value 0.09 ) units.

Among the business risk variables which affect litigation risk, size of the firm (coefficient 0.25, $p$-value 0.00) and cross-listing on a U.S. exchange (coefficient 0.40, $p$-value 0.00 ) tend to affect the limit of coverage positively. Noticeably, the size of the deductible is not related to coverage limit, once we control for the governance and business risk factors that affect litigation risk.

Analysis of insurance premium in Model (3) shows a reduction in premium by 3.14 ( $p$-value 0.00$)$ and 0.19 ( $p$-value 0.01$)$ units for a unit increase in insider value and outside blockholders, respectively. Premiums increase with incentive compensation (coefficient $0.15, p$-value 0.08 ), size of firm (coefficient $0.21, p$-value 0.00 ) or when the firm decides to list on a U.S. exchange (coefficient 0.59 , $p$-value 0.00 ). Residual obtained from the coverage equation in stage $\mathrm{I}$, that is, unexplained coverage, significantly increases the premiums (coefficient $0.67, p$-value 0.00 ). The premiums are significantly affected by prior litigation (coefficient $0.18, p$-value 0.02 ), even though coverage limits are not. Once governance and other business risk factors that affect litigation risk are controlled for, the size of the deductible is uncorrelated with premiums.

Business risk factors that affect coverage limits and premiums significantly across all models are size and U.S. exchange listing. Prior litigation experience of the firm significantly affects premiums but not coverage limits. Governance variables that are significantly related to coverage limits across models are outside blockholders, insider

\footnotetext{
${ }^{40}$ Note this is log of coverage limit.
} 
holdings (except model 1), incentive compensation and takeover deterrents. These governance variables, except for takeover deterrents, are also significantly related to premiums. $^{41}$

Although excess control is significantly related to coverage, its regression coefficient for premiums (coefficient $-0.70, p$-value 0.51 ), which is the sum of direct and indirect effect, (Eq. (4)), is not significant.

Next, we analyse the relation of excess control with firm performance. In the Rothschild and Stiglitz ${ }^{26}$ pooled equilibrium-adverse selection framework, firms attempt to distinguish themselves according to their levels of risk in the cross section. Accordingly, we undertake a pooled OLS analysis of performance. ${ }^{42}$ The results are shown in Table 5.

In Model 3 (Operating Profit ratio) and Model 4 (ROA), we control for governance characteristics, business risk factors and firm leverage. All models show that excess control is positively related to firm performance. The regression coefficient of excess control equals 0.22 ( $p$-value 0.00 ) in Model 3, and 0.15 ( $p$-value 0.00 ) in Model 4. Jointly, these results show firm insiders with excess control buy less D\&O insurance coverage and deliver superior firm performance, but excess control is unrelated with insurance premium. Our results also explain the lack of a direct relationship between D\&O insurance and firm performance in Chen and $\mathrm{Li}^{24}$ Our findings suggest this relationship may be mediated through excess control.

Our finding that excess control is negatively related to coverage limits is robust to an alternative specification in which we account for the monitoring of the firm by bondholders. The debt-to-assets ratio (leverage) is statistically insignificant and the results of Table 4 are qualitatively similar when leverage is included in the regressions. The result is not surprising because as leverage increases, bondholders can protect themselves against wealth transfer to stockholders via use of covenants and collateral and thus they need not dictate the $\mathrm{D} \& \mathrm{O}$ coverage decision by the firm. Our finding is consistent with observations made earlier in the literature ${ }^{43}$ that firms purchase $\mathrm{D} \& \mathrm{O}$ insurance primarily to protect their managers against shareholder lawsuits. Our results do not support bondholder monitoring hypothesis as a rationale for a decrease in coverage limits.

We also check the robustness of performance regression results using an alternative econometric model. We find the positive relationship between operating performance (EBITDA) and excess control is robust to control of industry fixed effects. ${ }^{44}$

Boyer $^{29}$ studies determinants of coverage limits and deductibles in purchase of D\&O insurance. The author's analysis suggests there are inertia effects in D\&O insurance

${ }^{41}$ One can argue that firms may elect to have coverage and this very fact may convey some information to the market. We construct a likelihood score based on Core (1997) and rerun regressions in Table 4. We find a high degree of collinearity between the likelihood score and our governance variables: excess control and insider value. Our independent variables, thus, capture the likelihood of a firm's decision to purchase D\&O insurance.

42 Alternatively, one can run period-by-period cross-sectional regressions and aggregate coefficients over time, as in Easley et al. (2002). However, since we have only three periods, an estimate obtained using this approach is imprecise. Baltagi (2002) suggests pooling of data in such circumstances to improve reliability.

${ }^{43}$ For example, Boyer (2008).

${ }^{44}$ Results available from authors upon request. 
Table 5 OLS regression estimates of firm performance on insider control, governance and business risk variables

\begin{tabular}{|c|c|c|c|c|}
\hline \multirow[t]{2}{*}{ Variable } & \multirow{2}{*}{$\frac{\text { Model } 1}{\text { EBITDA }}$} & \multirow{2}{*}{$\frac{\text { Model } 2}{R O A}$} & \multirow{2}{*}{$\frac{\text { Model } 3}{\text { EBITDA }}$} & \multirow{2}{*}{$\frac{\text { Model } 4}{R O A}$} \\
\hline & & & & \\
\hline \multirow[t]{2}{*}{ Excess control } & 0.22 & 0.14 & 0.22 & 0.15 \\
\hline & $(0.00)^{* * *}$ & $(0.00)^{* * *}$ & $(0.00)^{* * *}$ & $(0.00)^{* * *}$ \\
\hline \multirow[t]{2}{*}{ Insider value } & 0.38 & 0.24 & 0.14 & 0.05 \\
\hline & $(0.01)^{* * *}$ & $(0.00)^{* * *}$ & $(0.34)$ & $(0.58)$ \\
\hline \multirow[t]{2}{*}{ Leverage } & 0.15 & 0.12 & 0.14 & 0.11 \\
\hline & $(0.07)^{*}$ & $(0.04)^{* *}$ & $(0.05)^{*}$ & $(0.05)^{*}$ \\
\hline \multirow[t]{2}{*}{$\operatorname{Ln}($ size $)$} & 0.05 & 0.04 & 0.08 & 0.06 \\
\hline & $(0.04)^{* *}$ & $(0.01)^{* *}$ & $(0.00)^{* * *}$ & $(0.00)^{* * *}$ \\
\hline \multirow[t]{2}{*}{$\mathrm{D}$ (outside blockholder) } & & & 0.08 & 0.05 \\
\hline & & & $(0.03)^{* *}$ & $(0.07)^{*}$ \\
\hline \multirow{2}{*}{ Independent directors } & & & -0.47 & -0.36 \\
\hline & & & $(0.01)^{* * *}$ & $(0.01)^{* *}$ \\
\hline \multirow[t]{2}{*}{ Independent director appointments } & & & 0.27 & 0.25 \\
\hline & & & $(0.02)^{* *}$ & $(0.01)^{* * *}$ \\
\hline \multirow[t]{2}{*}{$\mathrm{D}(\mathrm{CEO}$ is chairman $)$} & & & 0.02 & 0.02 \\
\hline & & & $(0.56)$ & $(0.27)$ \\
\hline \multirow[t]{2}{*}{$\mathrm{D}$ (employment contract) } & & & 0.04 & 0.04 \\
\hline & & & $(0.59)$ & $(0.33)$ \\
\hline \multirow[t]{2}{*}{$\mathrm{D}$ (golden parachute) } & & & 0.00 & -0.00 \\
\hline & & & $(0.98)$ & $(0.88)$ \\
\hline \multirow[t]{2}{*}{$\mathrm{D}$ (takeover deterrents) } & & & 0.05 & 0.03 \\
\hline & & & $(0.14)$ & $(0.27)$ \\
\hline \multirow[t]{2}{*}{$\operatorname{Ln}(\mathrm{CEO}$ experience $)$} & & & 0.02 & 0.00 \\
\hline & & & $(0.37)$ & $(0.90)$ \\
\hline \multirow[t]{2}{*}{ Incentive compensation } & & & -0.04 & -0.01 \\
\hline & & & $(0.46)$ & $(0.82)$ \\
\hline \multirow[t]{2}{*}{$\mathrm{D}$ (prior litigation) } & & & 0.03 & 0.04 \\
\hline & & & $(0.30)$ & $(0.11)$ \\
\hline \multirow[t]{2}{*}{ D(U.S. operations) } & & & -0.01 & -0.01 \\
\hline & & & $(0.78)$ & $(0.68)$ \\
\hline \multirow{2}{*}{ D(U.S. exchange listing) } & & & -0.07 & -0.09 \\
\hline & & & $(0.07)^{*}$ & $(0.00)^{* * *}$ \\
\hline \multirow[t]{2}{*}{ Intercept } & -0.41 & -0.31 & -0.45 & -0.35 \\
\hline & $(0.01)^{* * *}$ & $(0.00)^{* * *}$ & $(0.02)^{* *}$ & $(0.01)^{* * *}$ \\
\hline$R^{2}$ & 0.27 & 0.23 & 0.41 & 0.36 \\
\hline Number of observations & 169 & 255 & 169 & 255 \\
\hline
\end{tabular}

$* * *, * *, *$ indicate statistical significance at the 1,5 or 10 per cent levels, respectively, in two-tailed tests. This table presents the results of regressions for firm performance using firm's governance and business risk variables. Variable definitions are given in Table 1. Dependent variables in these performance regressions are EBITDA and ROA. EBITDA is defined as operating income before depreciation scaled by total assets and ROA is defined as net income scaled by total assets. Excess control equals Insider Votes orthogonal to Insider Value. The sample includes 93 Canadian firms that disclose D\&O insurance data during two or more of following years: 1998, 2000 and 2002. Dollar values are expressed in constant 1995 Canadian dollars. Models 1 and 2 exclude governance and business risk variables from regression specifications whereas models 3 and 4 control for them. Heteroscedastically consistent $p$-values are reported in parentheses. 
purchase, in effect arguing for an AR (1) process for coverage limits. Our three-period unbalanced panel data restricts us from incorporating this specification in our firststage regressions of coverage limits in Table 4. An AR (1) specification, for our study, implies firms that decrease their coverage limits will continue to do so due to inertial effects. What effect such a specification bears on our main result, that firms with excess control simultaneously decrease D\&O coverage limits and deliver better operating performance, is an empirical question that cannot be answered using our data set. However, given the small sizes of premium paid relative to firm sizes, it is difficult to predict how inertial effects in D\&O insurance coverage limit explain changes in firm's performance. Since our results indicate a relation between D\&O insurance purchase and firm performance, inertia in D\&O insurance purchases may not be the key driver of our results.

Finally we discuss validity of these results taking into considerations various changes in the legal environment over the last decade. After the Sarbanes-Oxley Act, which made CEOs and accounting firms more accountable for their disclosures, and the Dodd-Frank Act, which emphasises transparency, the role of enterprise risk management (insurance included) has gained prominence. It is more likely that insurance companies have increased their due diligence to avoid scrutiny of their underwriting book by external agents (market or regulatory). In this event, it is highly unlikely that our basic premise, that D\&O insurance purchases convey information on insiders' private knowledge and/or behaviour beyond the easily observed governance characteristics, will alter and become insignificant.

\section{Conclusion}

We examine D\&O insurance purchases from the perspective of information asymmetry between a firm's managers and outsiders. Using insurance theory we argue that these purchases contain information about firm quality. Prior studies have shown linkages between D\&O insurance and corporate governance characteristics. However, since the characteristics typically studied are easily observable, the informatory role of D\&O insurance purchases stands diluted in the prior studies.

We construct a measure of excess control as insider voting rights unexplained by insider shareholdings and use it as proxy of private information. Using a panel data fixed-effects methodology we find that excess control is negatively linked to coverage limits and positively to firm performance. We control for observable governance characteristics, business factors that affect litigation risk and deductibles.

Our results show that $\mathrm{D} \& \mathrm{O}$ insurance purchases contain additional information not revealed in governance characteristics typically studied. The findings lend credence to the hypothesis put forth in Baker and Griffith ${ }^{17}$ that D\&O insurance contains information on "deep governance". Finally, our study's findings support the conclusions reached in earlier studies ${ }^{45}$ that there is merit to the demand for mandatory disclosures about D\&O insurance, since it conveys additional information to the market.

\footnotetext{
${ }^{45}$ Chalmers et al. (2002); Boyer (2008).
} 
The study can be seen as another step towards analysing whether D\&O insurance affects a firm's weighted average cost of capital, a topic left for future research. Bradley and $\mathrm{Chen}^{46}$ find that firms which have limited liability and indemnification (LLI) clauses embedded in employment contracts with directors have lower debt costs. To the extent that D\&O insurance is a substitute for LLI, one may expect to find similar results for D\&O insurance. In an unpublished work, Chen et al. ${ }^{47}$ report that firms which carry D\&O insurance also have higher cost of equity capital. In a related unpublished study, Lin et al. ${ }^{48}$ report that their evidence reveals higher levels of D\&O insurance are associated with higher loan spreads (or higher loan prices). To the extent that we find that firms decrease D\&O coverage limits and deliver improved operating performance, the findings in Lin et al. ${ }^{48}$ are consistent with our findings.

\section{Acknowledgements}

We would like to thank D. Scott Lee for his contributions to an earlier version of the paper. We also thank Nanda Rangan and Tyler Leverty for their valuable comments.

\section{References}

Attig, N., Fong, W.-M., Gadhuom, Y. and Lang, L.H.P. (2006) 'Effects of large shareholding on information asymmetry and stock liquidity', Journal of Banking and Finance 30(10): 2875-2892.

Baker, T. and Griffith, S.J. (2007) 'Predicting corporate governance risk: Evidence form directors' \& officers' liability insurance market', The University of Chicago Law Review 74(2): 487-544.

Baltagi, B.H. (2002) Econometric Analysis of Panel Data, Sussex, UK: John Wiley and Sons.

Boubakri, N., Boyer, M. and Ghalleb, N. (2008) Managerial opportunism in accounting choice: Evidence from Directors' \& Officers' liability insurance purchases, University of Montreal Working Paper.

Boyer, M.M. (2003) Is the demand for corporate insurance a habit? Evidence from Directors' and Officers' insurance, CIRANO Scientific Series.

Boyer, M.M. (2008) 'Three insights from the Canadian D\&O insurance market: Inertia, information and insiders', Connecticut Insurance Law Journal 14(1): 75-106.

Boyer, M.M. and Stern, L.H. (2012) 'Is corporate governance risk valued? Evidence from directors' and officers' insurance', Journal of Corporate Finance 18(2): 349-372.

Bradley, M. and Chen, C. (2011) 'Corporate governance and the cost of debt: Evidence from director limited liability and indemnification provisions', Journal of Corporate Finance 17(1): 83-107.

Chalmers, J.M., Dann, L.Y. and Harford, J. (2002) 'Managerial opportunism? Evidence from directors' and officers' insurance purchases', Journal of Finance 57(2): 609-636.

Chen, T.-J. and Li, S.-H. (2010) 'Directors' and officers' insurance, corporate governance, and firm performance', International Journal of Disclosure and Governance 7(3): 244-261.

Chen, Z., Li, O.Z. and Zou, H. (2011) 'Directors' and officers' liability insurance and the cost of equity capital', from www.ssrn.com/abstract=1837912, accessed 9 March 2012.

Chiappori, P.A. and Salaniè, B. (1997) 'Empirical contract theory: The case of insurance data', European Economic Review 41(3-5): 943-950.

Core, J.E. (1997) 'On the corporate demand for directors' and officers' insurance', Journal of Risk and Insurance 64(1): 63-87.

Core, J.E. (2000) 'The directors' and officers' insurance premium: An outside assessment of the quality of corporate governance', Journal of Law, Economics and Organization 16(2): 449-477.

\footnotetext{
${ }^{46}$ Bradley and Chen (2011).

${ }^{47}$ Chen et al. (2011).

${ }^{48}$ Lin et al. (2012).
} 
450

Crocker, K.J. and Snow, A. (2011) 'Multidimensional screening in insurance markets with adverse selection', Journal of Risk and Insurance 78(2): 287-307.

Cummins, J.D. and Outreville, J.F. (1987) 'An international analysis of underwriting cycles in propertyliability insurance', Journal of Risk and Insurance 54(2): 246-262.

Demsetz, H. and Villalonga, B. (2001) 'Ownership structure and corporate performance', Journal of Corporate Finance 7(3): 209-233.

Doherty, N. and Schlesinger, H. (1995) 'Severity risk and the adverse selection of frequency risk', Journal of Risk and Insurance 62(4): 649-665.

Easley, D., Hvidkjaer, S. and O'Hara, M. (2002) 'Is information risk a determinant of asset returns?' Journal of Finance 57(5): 2185-2221.

Fama, E.F. and Jensen, M. (1983) 'Separation of ownership and control', Journal of Law and Economics 26(2): 301-325.

Frieswick, K. (2002) 'New reality: Less for more. Coping with the bear market in directors' and officers' liability insurance', CFO Magazine 18(4): 37-40.

Hazen, T.L. and Hazen, L.L. (2012) 'Duties of nonprofit corporate directors - emphasizing oversight responsibilities', North Carolina Law Review 90(6), forthcoming.

Holderness, C.G. (1990) 'Liability insurers as corporate monitors', International Review of Law and Economics 10(2): 115-129.

Kyrtsis, A.-A. (2011) 'Insurance of techno-organizational ventures and procedural ethics: Lessons from the deepwater horizon explosion', Journal of Business Ethics 103(1): 45-61.

Lin, C., Officer, M.S., Wang, R. and Zou, H. (2012) 'Directors' and officers' liability insurance and loan spreads', from www.ssrn.com/abstract $=1865679$, accessed 9 March 2012.

Lin, C., Officer, M.S. and Zou, H. (2011) 'Directors' and officers' liability insurance and acquisition outcomes', Journal of Financial Economics 102(3): 507-525.

Milidonis, A. and Stathopoulos, K. (2011) 'Do U.S. insurance firms offer the "wrong" incentives to their executives?' Journal of Risk and Insurance 78(3): 643-672.

O'Sullivan, N. (1997) 'Insuring the agents: The role of directors' and officers' insurance in corporate governance', Journal of Risk and Insurance 64(3): 545-556.

O'Sullivan, N. (2002) 'The demand for directors' and officers' insurance by large UK companies', European Management Journal 20(5): 574-583.

O'Sullivan, N. (2009) 'The impact of directors' and officers' insurance on audit pricing: Evidence from UK companies', Accounting Forum 33(2): 146-161.

Park, Y.W. and Shin, H.H. (2004) 'Board composition and earnings management in Canada', Journal of Corporate Finance 10(3): 431-457.

Puelz, R. and Snow, A. (1994) 'Evidence on adverse selection: Equilibrium signaling and cross-subsidization in the insurance market', Journal of Political Economy 102(2): 236-257.

Romano, R. (1989) 'What went wrong with directors' and officers' liability insurance?' Delaware Journal of Corporate Law 14(1): 1-27.

Rothschild, M. and Stiglitz, J.E. (1976) 'Equilibrium in competitive insurance markets: The economics of markets with imperfect information', Quarterly Journal of Economics 90(4): 629-649.

Schmalensee, R. (1989) 'Inter-industry studies of structure and performance', in R. Schmalensee and R.D. Willig (eds.) Handbook of Industrial Organization. Vol II, Amsterdam: Elsevier Science Publishers B.V.

\section{About the Authors}

Manu Gupta is Assistant Professor of Finance at Virginia Commonwealth University. His research interests include corporate governance, executive compensation, earnings manipulation and regulatory institutions. He has published in Journal of Law and Economics, Journal of Banking and Finance, Journal of Risk and Insurance, Journal of Business Finance and Accounting and The Geneva Papers on Risk and Insurance-Issues and Practice. He has been quoted in Financial Times, London, The Washington Post and St. Louis Post Dispatch. 
Puneet Prakash is Assistant Professor in Finance, Insurance and Real Estate Department at Virginia Commonwealth University. His research interests include risk management and corporate finance. He teaches risk, insurance and corporate finance courses. He has published in Journal of Risk and Insurance, Journal of Economics and Business, and The Geneva Papers on Risk and Insurance-Issues and Practice. He has won competitive research grants from the Dean of School of Business at VCU, and presented research papers at both national and international conferences. 